\title{
In Vivo Gene Therapy for Hyperlipidemia: Phenotypic Correction in Watanabe Rabbits by Hepatic Delivery of the Rabbit LDL Receptor Gene
}

\author{
Jia Li, “ Bingliang Fang, * Randy C. Eisensmith, ${ }^{\star}$ Xiao Hong Chen Li, ${ }^{\prime}$ Igor Nasonkin, ${ }^{*}$ Yen-Chiu Lin-Lee, $\$$ \\ Martha P. Mims, ${ }^{5}$ Angela Hughes," Charles D. Montgomery," Jeremy D. Roberts, ' Thomas S. Parker, \\ Daniel M. Levine,' and Savio L. C. Woo** \\ *Department of Cell Biology, ${ }^{8}$ Department of Medicine, and "Center of Comparative Medicine, Baylor College of Medicine, Houston, \\ Texas 77030; ${ }^{\ddagger}$ Howard Hughes Medical Institute, Baylor College of Medicine, Houston, Texas 77030; and 'The Rogosin Institute, \\ The New York Hospital/Cornell Medical Center, New York 10021
}

\begin{abstract}
Elevations of plasma total or LDL cholesterol are major risk factors for cardiovascular disease. Efforts directed at preventing and treating cardiovascular disease have often focused on reducing the levels of these substances in the blood. The Watanabe Heritable Hyperlipidemic Rabbit, which has exceedingly high plasma cholesterol levels resulting from an LDL receptor deficiency, provides an excellent animal model for testing new treatments. A recombinant adenoviral vector containing the rabbit $L D L$ receptor cDNA was administered to Watanabe rabbits. Plasma total cholesterol levels in the treated animals were reduced from $825.5 \pm 69.8$ (mean $\pm S D$ ) to $247.3 \pm 61.5 \mathrm{mg} / \mathrm{dl} 6 \mathrm{~d}$ after infusion. These animals also demonstrated a $300-400 \%$ increase in plasma levels of HDL cholesterol and apo AI $10 \mathrm{~d}$ after treatment. As a result, the LDL:HDL ratio exhibited a dramatic decrease. Because only the rabbit LDL receptor gene was used for treatment, the results strongly suggest that the elevations of plasma HDL cholesterol and apo AI were secondary to a reduction in plasma total cholesterol in the treated animals. These results suggest an inverse relationship between plasma LDL and HDL cholesterol levels and imply that reduction of LDL cholesterol levels may have a beneficial effect on plasma HDL cholesterol. (J. Clin. Invest. 1995. 95:768-773.) Key words: gene therapy • adenovirus - hyperlipidemia $\cdot$ LDL receptor $\cdot$ HDL
\end{abstract}

Address correspondence to Savio L. C. Woo, Ph.D., Department of Cell Biology, Baylor College of Medicine, One Baylor Plaza, Houston, TX 77030. Phone: 713-798-6080; FAX: 713-798-8640.

Received for publication 17 March 1994 and in revised form 29 September 1994.

1. Abbreviations used in this paper: Adv/RSV-hAAT, recombinant adenovirus containing human $\alpha_{1}$-antitrypsin CDNA under transcriptional control of RSV long terminal repeat; Adv/RSV-rbLDLR, recombinant adenovirus containing rabbit LDL receptor CDNA under transcriptional control of RSV long terminal repeat; CE, cholesteryl ester; CETP, cholesteryl ester transfer protein; CHD, Coronary heart disease; EHLWHHR, English half-lop rabbits bearing the Watanabe heritable hyperlipidemic rabbit trait; EHL-ww, English half-lop rabbit; FH, familial hypercholesterolemia; LTR, long terminal repeat; NZW, New Zeland white; RSV, Rous sarcoma virus.

J. Clin. Invest.

(c) The American Society for Clinical Investigation, Inc.

0021-9738/95/02/0768/06 \$2.00

Volume 95, February 1995, 768-773

\section{Introduction}

Hypercholesterolemia contributes to a number of human diseases, including coronary atherosclerosis, myocardial infarction, and stroke. Identification of the molecular defect that causes familial hypercholesterolemia (FH), ${ }^{1}$ one of the most devastating of the lipid disorders, has provided insight into lipid metabolism and aided in the development of new treatments for hyperlipidemia and atherosclerosis. In normal individuals, plasma LDL is cleared primarily via LDL receptors on the surface of hepatocytes. In FH patients, LDL is cleared much more slowly than normal because of mutations in the LDL receptor gene that block the synthesis or transport of the LDL receptor to the cell surface, inhibit LDL binding to the receptor, or prevent internalization of the LDL/receptor complex (1). FH heterozygotes, who comprise 1 out of every 500 individuals in the U.S. population, exhibit twofold elevations in plasma cholesterol levels and often begin to develop tendon xanthomas and coronary atherosclerosis in their twenties (2). FH homozygotes, who comprise one out of every one million individuals in the U.S. population, exhibit fourfold elevations in plasma cholesterol levels, often develop cutaneous xanthomas before $4 \mathrm{yr}$ of age, display well-developed coronary heart disease in childhood, and frequently die before age $20(3,4)$.

Current treatments for $\mathrm{FH}$ heterozygotes have focused on upregulating expression of the normal LDL receptor gene (5). For example, drugs that block bile acid recycling and cholesterol biosynthesis reduce intracellular cholesterol levels and result in upregulation of LDL receptor gene expression, leading to a decrease in plasma cholesterol levels (6-8). This mode of therapy is much less effective in FH homozygotes, because neither copy of the LDL receptor gene produces a fully functional receptor. These patients have been treated by plasma exchange for removal of LDL (9) or by portacaval anastomosis (10) with varying degrees of success. The precipitous decrease in plasma cholesterol levels, from $>1,000 \mathrm{mg} / \mathrm{dl}$ to $200-300 \mathrm{mg} / \mathrm{dl}$, following liver transplantation (11), suggests that therapies that restore functional LDL receptors to the surface of hepatocytes would have promise in the treatment of FH homozygotes.

Progress in developing new methods for the treatment of hypercholesterolemia and associated conditions has been greatly aided by the identification and characterization of animal models. One such model, the Watanabe heritable hyperlipidemic rabbit, has been available since the late 1970s (12). Watanabe rabbits bear an in-frame deletion of 12 nucleotides that eliminates four amino acids from the cysteine-rich ligand binding domain of the LDL receptor gene (13). This deletion in LDL receptor prevents LDL receptor-mediated uptake of LDL particles to the liver, resulting in dramatic increases in plasma cholesterol levels. This rabbit model, together with LDL receptor 
knockout mice (14) and other similar animal models, are now being used to determine the potential of various gene transfer methods for the treatment of hyperlipidemias (15-17). DNAbased and retrovirus-mediated gene delivery has been attempted respectively in vivo and ex vivo in Watanabe rabbits $(15,16)$. The ex vivo approach has also been examined in nonhuman primates (17) and most recently in humans (18). Thus far, retrovirus-mediated approaches are limited by the low efficiency of therapeutic gene delivery to target organs and by the fact that permanent transduction can occur only in dividing cells. In contrast, adenovirus-mediated gene delivery is highly efficient, can be used to transduce nondividing cells, and recombinant adenoviral vectors can be conveniently produced and administered to experimental animals. In vivo administration of a recombinant adenovirus containing the LDL receptor gene has been shown to increase the clearance of labeled VLDL in LDL receptor knockout mice (14), resulting in a complete absence of LDL in plasma and decrease plasma total cholesterol level in Watanabe rabbits (19). In the present study, a recombinant adenovirus containing the rabbit LDL receptor cDNA driven by the Rous sarcoma virus (RSV) promoter (Adv/RSVrbLDLR) has been administered to Watanabe rabbits in vivo by splenic vein infusion. Plasma levels of total cholesterol were reduced by $75 \%$ at $6 \mathrm{~d}$ after treatment, whereas HDL cholesterol and apo AI levels were subsequently increased by three to fourfold.

\section{Methods}

Materials. English half-lop rabbits bearing the Watanabe heritable hyperlipidemic rabbit trait (EHL-WHHR) were bred at The Rogosin Institute at the New York Hospital-Cornell Medical Center. 10 females were superovulated and artificially inseminated to produce enlarged litters of the same age for these experiments. Littermates (polyzygotic) were then sex-matched across experimental groups to minimize variability, thereby increasing the statistical power of the experimental design (20). A rabbit LDL receptor (rbLDLR) cDNA clone with a truncation that included part of the signal peptide region (18) was kindly provided by Dr. Joseph Goldstein (University of Texas Southwestern Medical Center at Dallas). A recombinant adenovirus containing the Escherichia coli $\beta$-galactosidase gene driven by the RSV promoter (Adv/RSV- $\beta$ gal) was kindly provided by Dr. Michel Perricaudet (Institut Gustave Roussy, at Villejuif, France).

Construction of recombinant adenovirus with rabbit $L D L$ receptor gene. Approximately $200 \mathrm{bp}$ of DNA was added to the $5^{\prime}$ end of the rabbit LDL receptor CDNA clone to regenerate the translation initiation codon and the signal peptide. This. was done through the annealing and ligation of overlapping oligonucleotides designed according to the human LDL receptor sequence (21). The resultant cDNA fragment was cloned into the EcoRV site of the E1A-adenovirus transfer vector pAdL1/RSV $(22,23)$. This construct was cotransfected with the plasmid pJM17 into the adenovirus packaging cell line 293. Recombinant adenovirus clones were plaque purified and amplified as previously described (24). The viral titer, as determined by OD, varied from 1 to $3 \times 10^{11}$ particles $/ \mathrm{ml}$.

Rabbit $L D L$ receptor functional assay. In vitro binding, uptake, and degradation of ${ }^{125}$ I-labeled human LDL by primary hepatocytes of Watanabe rabbits was measured after transduction by Adv/RSVrbLDLR in vitro to confirm the function of the rbLDLR cDNA. Watanabe rabbit hepatocytes were isolated and cultured in SUM medium (tyrosine-free MEM/Waymouth's supplemented with growth factors) overnight (25). The hepatocytes were transduced with Adv/RSVrbLDLR at $0,1,10$, and 100 particles/cell for $4 \mathrm{~h}$. The medium was then changed and the cells were cultured overnight. Binding, uptake, and degradation of ${ }^{125}$ I-labeled human LDL were measured as described $(26,27)$.

In vivo delivery of recombinant adenovirus via splenic vein infusion. New Zealand white (NZW) rabbits were anesthetized with $0.5 \mathrm{ml} / \mathrm{kg}$ of an anesthetic containing a combination of ketamine $(1.43 \mathrm{mg} / \mathrm{ml})$, xylazine $(0.286 \mathrm{mg} / \mathrm{ml})$, and acepromazine $(0.047 \mathrm{mg} / \mathrm{ml})$. EHLWHHR rabbits were anesthetized using the respiratory anesthetic Aerrane (isoflurane). Recombinant adenovirus suspended in buffer $(10 \mathrm{mM}$ Tris-Cl, $1 \mathrm{mM} \mathrm{MgCl}, 10 \%$ glycerol) was diluted with PBS to $10 \mathrm{ml}$ and then infused through splenic vein injection.

To test LDL receptor gene expression in vivo, the adenovirus Adv/ RSV-rbLDLR was infused into the portal circulation of Watanabe rabbits. Hepatocytes were isolated from these rabbits $3 \mathrm{~d}$ postinfusion, and the binding and uptake of ${ }^{125}$ I-labeled human LDL were measured as described above. Hepatocytes from rabbits infused with a recombinant adenovirus bearing the human $\alpha_{1}$-antitrypsin gene (Adv/RSV-hAAT) (28) were used as a negative control.

Virus transfection efficiency and tissue distribution. $0,1 \times 10^{11}, 2$ $\times 10^{11}, 4 \times 10^{11} \mathrm{Adv} / \mathrm{RSV}$ - $\beta$ gal particles/kg body weight were infused into NZW rabbits. $3 \mathrm{~d}$ after infusion, hepatocytes were isolated and stained for $\beta$-galactosidase activity as previously described (29) to determine the in vivo transduction efficiency. A sample of liver tissue was also collected at this time for histopathological analysis. At 1 or $4 \mathrm{wk}$ postinfusion, 10 different tissue types were collected. Genomic DNA was extracted from frozen tissue samples, and serial dilutions containing $1 \mu \mathrm{g}$ to $1 \mathrm{ng}$ were used as templates in a semiquantitative PCR assay to determine the presence of Adv/RSV- $\beta$ gal DNA as previously described (24). DNA isolated from 1 to $10^{6}$ viral particles was amplified in parallel as positive controls. A 500-bp PCR product was generated from amplification with primers located in the RSV promoter (5'-GTAAGGTGGTACCATCGT- $3^{\prime}$ ) and the $\beta$-galactosidase gene ( $5^{\prime}$-GGATGTGCTGCAAGGCGA-3'). Viral DNA copy numbers per cell were determined by comparing the band density of these products on agarose gel to those of PCR products from the positive controls.

Plasma total, HDL and LDL cholesterol, and apo AI determinations. Six sets of age- and sex-matched Watanabe rabbits were infused with recombinant Adv/RSV-rbLDLR, Adv/RSV-hAAT, or buffer through splenic vein injection. Plasma cholesterol level was determined twice weekly both pre- and postinfusion in all animals. Rabbits infused with Adv/RSV-hAAT and buffer served as negative controls. Total plasma cholesterol levels were determined by an enzymatic method using the Cholesterol/HP kit from Boehringer-Mannheim Diagnostics (Indianapolis, IN) in a 704 Analyzer (Hitachi Sci. Instrs., Mountain View, CA). HDL-cholesterol level was measured from the supernatant after precipitating the other plasma lipoproteins with $0.05 \mathrm{M} \mathrm{MgCl}_{2}$ and $0.05 \%$ dextran sulfate (30). An ELISA with a goat anti-rabbit apo AI IgG from Parke-Davis (Ann Arbor, MI) was used to determine serum apo AI levels (31).

Direct measurement of cholesterol level in VLDL, LDL, and HDL. To examine alterations in cholesterol levels of different lipoprotein components, VLDL, LDL, and HDL particles were separated by fast peptide liquid chromatography (FPLC) (32). $500 \mu$ l of plasma from EHL-ww or $200 \mu$ l of plasma from EHL-WHHR were injected onto Superose 6 and 12 columns connected in series and then eluted at $0.5 \mathrm{ml} / \mathrm{min}$ with PBS containing $1 \mathrm{mg} / \mathrm{ml}$ EDTA (pH 7.5). Fractions were collected $(0.5 \mathrm{~min}, 0.25 \mathrm{ml})$ and analyzed for total cholesterol by a modification of the cholesterol oxidase enzymatic method adapted to the Roche COBAS Fara (Branchburg, NJ) (33).

\section{Results}

Functional assay of the recombinant Adv/RSV-rbLDLR vector. A recombinant adenovirus containing the rbLDLR cDNA under the transcriptional control of the RSV long terminal repeat (LTR) promotor was constructed (Adv/RSV-rbLDLR). The functionality of the recombinant vector was assayed by measuring the binding, uptake, and degradation of ${ }^{125} \mathrm{I}$-labeled human 


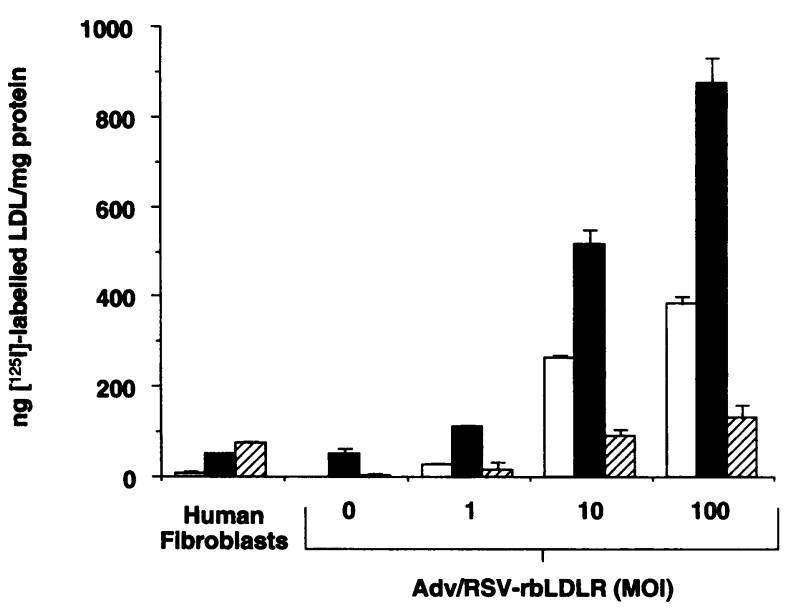

Figure 1. A recombinant adenovirus containing the rbLDLR cDNA driven by the RSV LTR promoter (Adv/RSV-rbLDLR) was constructed as described in Methods. The function of this virus was tested in vitro by measuring the binding ( $\square$ ), uptake ( $\square$ ), and degradation ( $\square$ ) of ${ }^{125}$ I-labeled human LDL in primary Watanabe hepatocytes transduced at different multiplicities of infection (MOI). Each point represents the mean \pm SD of three separate determinations from the same hepatocyte preparation.

LDL in LDL receptor-deficient Watanabe rabbit hepatocytes after viral transduction in vitro (Fig. 1). Although nontransduced Watanabe hepatocytes exhibited minimal uptake and degradation of ${ }^{125} \mathrm{I}-\mathrm{LDL}$, the Adv/RSV-rbLDLR vector successfully restored LDL receptor function in the LDL receptor-deficient hepatocytes in a dose-dependent manner.

In a pilot experiment, two Watanabe rabbits were infused with $4 \times 10^{11}$ particles/ $\mathrm{kg}$ of Adv/RSV-rbLDLR. $3 \mathrm{~d}$ after infusion, hepatocytes isolated from rabbits receiving the rbLDLR gene bound and internalized six times more ${ }^{125} \mathrm{I}-\mathrm{LDL}$ than hepatocytes isolated from animals treated with the control virus Adv/RSV-hAAT ( $193.25 \pm 17.99$ vs. $32.25 \pm 4.10 \mathrm{ng} / \mathrm{mg}$ cell protein).

Hepatocyte transduction efficiency and tissue distribution of viral DNA after splenic vein infusion of Adv/RSV- $\beta$ gal in normal rabbits. The efficiency of adenovirus-mediated gene delivery to rabbit hepatocytes in vivo was determined by infusing various doses of the recombinant adenovirus Adv/RSV$\beta$ gal into the splenic vein of NZW rabbits. Buffer infusion served as a negative control. The hepatocytes were isolated 2 d postinjection, followed by staining with $\mathrm{X}$-gal. $80 \%$ and $88 \%$ of hepatocytes were stained blue at doses of $4 \times 10^{11}$ and 10 $\times 10^{11}$ viral particles $/ \mathrm{kg}$ body wt, respectively. Semiquantitative PCR was used to estimate the amount of recombinant adenoviral DNA in brain, kidney, heart, liver, lung, muscle, pancreas, spleen, stomach, and testes after in vivo infusion of 4 $\times 10^{11}$ viral particles $/ \mathrm{kg}$. $1 \mathrm{wk}$ after viral infusion, high concentrations of viral DNA (700 copies/1,000 cells) could be detected in the liver and spleen. Viral DNA concentrations were one to two orders of magnitude lower (7-70 copies/1,000 cells) in the kidney, lung, stomach, and pancreas. Less than one copy of viral DNA per 1,000 cells was detectable in the brain, heart, and skeletal muscle. $4 \mathrm{wk}$ after infusion, viral DNA concentrations were below the detection limit of 0.7 copies/ 1,000 cells in all tissues. The tissue distribution and the lack of persistence of the viral sequences in transduced cells in vivo

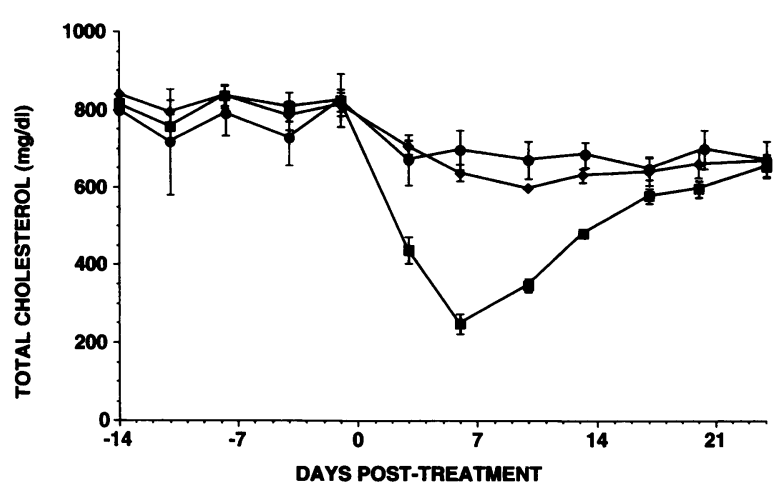

Figure 2. Total plasma cholesterol levels in Watanabe rabbits after infusion of $4 \times 10^{11}$ viral particles/kg body weight of Adv/RSV$\operatorname{rbLDLR}(\bullet), \operatorname{Adv} / \operatorname{RSV}-h A A T(\bullet)$, or buffer $(\bullet)$ into the splenic vein. Each treatment group contained six age- and sex-matched animals. Multiple determinations were made before infusion to establish pretreatment levels. Blood samples were drawn twice weekly after infusion and total cholesterol levels were determined. By $6 \mathrm{~d}$ postinfusion, total cholesterol levels in the rabbits treated with Adv/RSV-rbLDLR were significantly reduced $(P<0.001)$ relative to those treated with Adv/RSV-hAAT or buffer. Standard errors are indicated for each data point.

are similar to those observed in other animal systems $(19,23$, 24, 29, 34).

Plasma cholesterol reduction in Watanabe rabbits after delivery of the rbLDLR gene. 18 Watanabe rabbits were divided into 6 age- and sex-matched sets. One member of each set received a splenic vein infusion of either $4 \times 10^{11}$ particles $/ \mathrm{kg}$ of Adv/RSV-rbLDLR, Adv/RSV-hAAT, or the buffer in which the viruses were suspended. $6 \mathrm{~d}$ after treatment, plasma total cholesterol in the animals treated with Adv/RSV-rbLDLR was significantly decreased as compared with the pretreatment levels $(825.5 \pm 69.8 \mathrm{mg} / \mathrm{dl}$ at day -1 vs. $247.3 \pm 61.5 \mathrm{mg} / \mathrm{dl}$ at day 6 ; $P<0.001$ ) (Fig. 2). These levels were also significantly lower than those observed in either Adv/RSV-hAAT-treated control group $(638.8 \pm 53.6 \mathrm{mg} / \mathrm{dl}$ at day $6, P<0.001)$ or the buffertreated control group $(696.0 \pm 124.1 \mathrm{mg} / \mathrm{dl}$ at day $6, P<0.001)$, despite a small but significant decrease in plasma total cholesterol levels that also occurred in these latter two groups over this same time period $[824.7 \pm 75.4 \mathrm{mg} / \mathrm{dl}$ (day -1) vs. $638.3 \pm 53.6 \mathrm{mg} / \mathrm{dl}$ (day 6) for Adv/RSV-hAAT-treated group; $842.7 \pm 164.6$ (day -1 ) vs. $696.0 \pm 124.1 \mathrm{mg} / \mathrm{dl}$ (day 6) for the buffer-treated group]. Plasma total cholesterol values in the animals receiving Adv/RSV-rbLDLR reached their lowest levels 1 wk after infusion and then gradually increased, returning to control levels after $3 \mathrm{wk}$. Thus this recombinant vector efficiently reduced plasma cholesterol in the Watanabe rabbits, although this effect was transient, as seen previously in other animal models.

Elevation of plasma HDL cholesterol and apo AI in Watanabe rabbits after delivery of the rbLDLR gene. Treatment with Adv/RSV-rbLDLR also caused a significant elevation in HDL cholesterol and apo AI levels. $10 \mathrm{~d}$ after treatment, HDL-cholesterol levels in these animals were increased four to fivefold as compared with pretreatment levels $[19.8 \pm 4.0 \mathrm{mg} / \mathrm{dl}$ (day 10) vs. $4.0 \pm 0.0 \mathrm{mg} / \mathrm{dl}$ (day 0$) ; P<0.005]$ or to those observed in either the Adv/RSV-hAAT-treated control group (5.3 \pm 3.0 $\mathrm{mg} / \mathrm{dl}, P<0.002)$ or the buffer-treated group $(3.3 \pm 3.0 \mathrm{mg} /$ dl, $P<0.001$ ) (Fig. 3). At this same time point, apo AI levels 


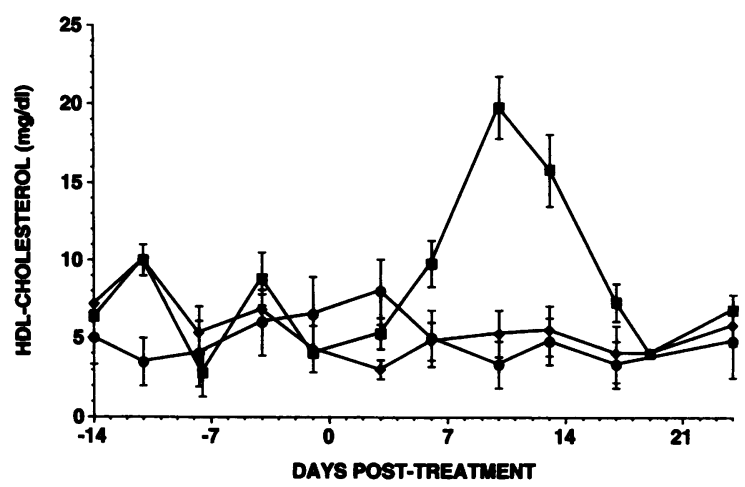

Figure 3. Plasma HDL-cholesterol levels in Watanabe rabbits after infusion of Adv/RSV-rbLDLR ( $\bullet$ ), Adv/RSV-hAAT ( $\bullet$ ), or buffer $(\bullet)$. Each treatment group contained four age- and sex-matched animals. Multiple determinations were made before infusion to establish pretreatment levels. Blood samples were drawn twice weekly after infusion and HDL-cholesterol levels were determined. By $10 \mathrm{~d}$ postinfusion, HDLcholesterol levels in the rabbits treated with Adv/RSV-rbLDLR were significantly reduced $(P<0.01)$ relative to those treated with Adv/ RSV-hAAT or buffer. Standard errors are indicated for each data point.

in animals treated with Adv/RSV-rbLDLR $(6.44 \pm 0.34 \mathrm{mg} / \mathrm{dl})$ were also significantly increased relative to those infused with either Adv/RSV-hAAT $(0.97 \pm 0.66 \mathrm{mg} / \mathrm{dl}, P<0.001)$ or buffer $(1.54 \pm 0.94 \mathrm{mg} / \mathrm{dl}, P<0.005$ ) (Fig. 4$)$. HDL cholesterol and apo AI both returned to within the pretreatment range by 3 wk. This effect was specific for the rbLDLR gene, because it was not observed in buffer- or control virus-treated groups. Although the lowest plasma cholesterol levels were reached in the Watanabe rabbits $6 \mathrm{~d}$ after delivery of the rbLDLR gene, the highest plasma HDL-cholesterol levels were reached at 10 d posttreatment.

Decrease of $L D L$ cholesterol after adenovirus-mediated $L D L$ receptor gene delivery in vivo. FPLC was combined with enzymatic methods to determine the relative contributions of LDL-, HDL-, and VLDL-cholesterol changes to the observed

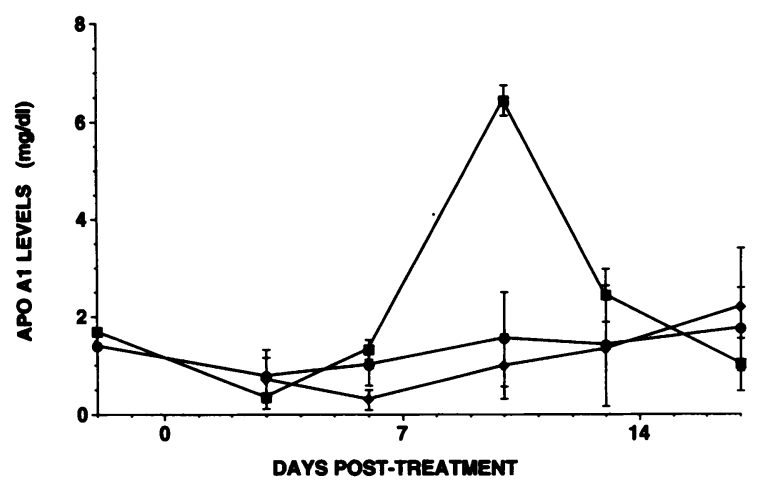

Figure 4. Plasma apo AI levels in Watanabe rabbits after infusion of Adv/RSV-rbLDLR ( $\bullet$ ), Adv/RSV-hAAT ( $\bullet$ ), or buffer ( $\bullet$ ). Each treatment group contained four age- and sex-matched animals. Multiple determinations were made before infusion to establish pretreatment levels. Blood samples were drawn twice weekly after infusion and HDLcholesterol levels were determined. By $10 \mathrm{~d}$ postinfusion, HDL-cholesterol levels in the rabbits treated with Adv/RSV-rbLDLR were significantly reduced $(P<0.005)$ relative to those treated with Adv/RSVhAAT or buffer. Standard errors are indicated for each data point.
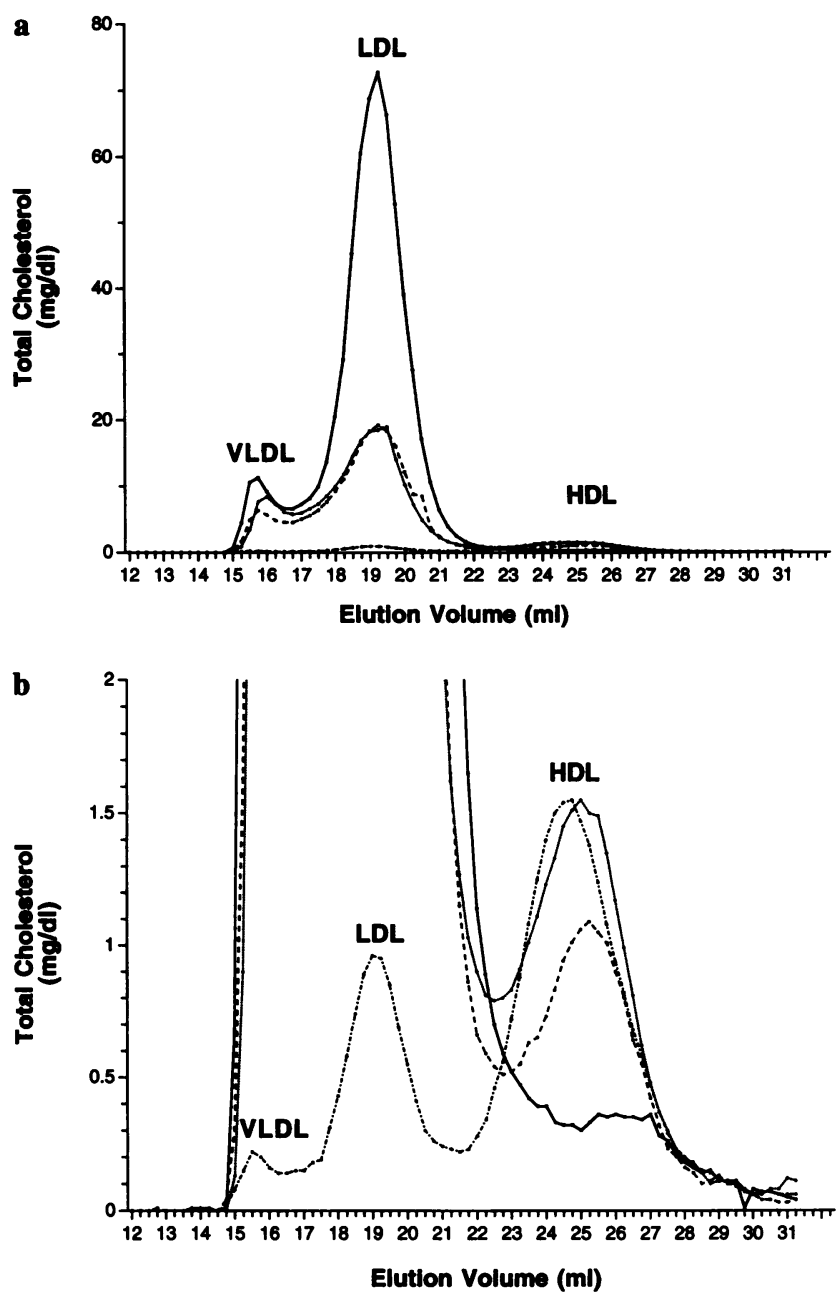

Figure 5. Cholesterol level changes in each lipoprotein component measured by fast peptide liquid chromatography combined with a modified cholesterol oxidase enzymatic method. EHL-WHHR rabbit (day -1), -; EHL-WHHR rabbit (day +6), - - - ; EHL-WHHR rabbit (day $+10), \cdots$; EHL-ww rabbit, $-\cdot-\cdot-$. The EHL-WHHR rabbit has increased LDL cholesterol $(a)$ and decreased HDL-cholesterol level $(b)$ as compared with EHL-ww rabbit. $6 \mathrm{~d}$ after Adv/RSV-rbLDLR infusion, LDL-cholesterol level decreased by $75 \%(a) .10 \mathrm{~d}$ after Adv/ RSV-rbLDLR infusion, HDL-cholesterol level increased by $300 \%(b)$.

decreases in total cholesterol levels. Serum samples were analyzed from one EHL-ww rabbit (the EHL-WHHR genetic background strain) and from Watanabe rabbits before and at 6 and 10 d after treatment with Adv/RSV-rbLDLR, Adv/RSV-hAAT, or buffer (Fig. 5). LDL receptor deficiency in the EHL-WHHR rabbit caused a large increase in the LDL-cholesterol level and a large decrease in the HDL-cholesterol level as compared with the non-LDLR-deficient EHL-ww rabbit (Fig. 5, $a$ and $b$ ). 6 d after Adv/RSV-LDLR infusion (Fig. 5a), LDL-cholesterol levels in the EHL-WHHR animal decreased by $75 \%$ relative to pretreatment levels $(732.9 \mathrm{mg} / \mathrm{dl}$ at day $-1 \mathrm{vs} .211 .5 \mathrm{mg} / \mathrm{dl}$ at day 6), and this drop in LDL-cholesterol levels was the major contributor to the decrease in total cholesterol. No LDL-cholesterol decreases occurred in either of the control animals (data not shown). LDL receptor gene delivery also increased the plasma HDL-cholesterol level in Watanabe rabbits by $300 \%$ at $10 \mathrm{~d}$ posttreatment $(8.7 \mathrm{mg} / \mathrm{dl}$ at day $-1 \mathrm{vs} .28 .2 \mathrm{mg} / \mathrm{dl}$ at day 
10) (Fig. 5b), a level nearly identical to that found in the EHLww rabbit.

\section{Discussion}

Adenovirus-mediated gene delivery has been shown to be an efficient method for in vivo gene delivery in mouse and dog models by our laboratory and others $(19,23,24,29,34,35)$. In this study, the efficiency of direct gene transfer of the rabbit LDL receptor into the liver of Watanabe rabbits was examined as a model of gene therapy for hyperlipidemia. The resulting decreases in plasma total cholesterol levels from 825.5 \pm 69.8 to $247.3 \pm 61.5 \mathrm{mg} / \mathrm{dl}$ after gene delivery demonstrates the feasibility of gene therapy for FH by in vivo delivery of Adv/RSVrbLDLR. As in other systems involving adenoviral-mediated gene delivery in vivo $(14,19,23,24,29,34)$, the therapeutic effect was transient in these rabbits. Although long-term therapeutic effects may be achievable with adenoviral vectors modified for increased persistence, the current study illustrates the principle that hyperlipidemia can be ameliorated by a single inoculation of a vector containing a therapeutic gene.

Previous studies on adenovirus-mediated LDL receptor gene delivery have shown increased clearance of ${ }^{125} \mathrm{I}-\mathrm{VLDL}$ in LDL receptor knockout mice (14), resulting in a complete reduction of plasma LDL and decreased total cholesterol in Watanabe rabbits (19). In the present study, we observed not only a significant decrease in total cholesterol but also observed a significant elevation of plasma HDL cholesterol in the Watanabe rabbits treated with the rabbit LDL receptor. Similar increases in HDL cholesterol were not observed in the mouse model (14). Although the mechanisms responsible for this increase in HDL cholesterol are not clear, the reduction of the LDL pool caused by the treatment with the LDL receptor may limit the transfer of cholesterol from HDL to LDL that is mediated by cholesteryl ester transfer protein (CETP).

CETP transfers cholesterol esters from HDL particles to less dense apo B-containing lipoprotein in exchange for triglyceride. It is highly active in both human and rabbits (36) but is apparently inactive in mice (37). CETP activity correlates directly with the LDL-cholesterol level and inversely with HDLcholesterol level. As a result, normal mice have very low LDLand high HDL-cholesterol levels (14), whereas humans and rabbits display a relatively high LDL:HDL ratio. Although HDL levels remain unaltered after LDL receptor knockout in mice (14), HDL levels are greatly reduced in LDL receptor-deficient rabbits (Fig. 5, $a$ and $b$ ). LDL receptor deficiency results in a vastly increased LDL pool that serves as an acceptor of HDLcholesteryl esters. The high CETP activity in Watanabe rabbits (38) may transfer a large amount of HDL CE to LDL particles, creating more small HDL particles that are rapidly degraded. Similarly, FH patients have low HDL levels and elevated CETP activity (39).

After LDL receptor gene delivery to the Watanabe rabbit, the LDL pool was decreased. As a secondary effect of decreased transfer of HDL cholesterol to LDL, HDL-cholesterol levels were increased. This conclusion is supported by the fact that plasma total cholesterol reached its lowest level $6 \mathrm{~d}$ postinfusion, whereas HDL cholesterol peaks at $10 \mathrm{~d}$ postinfusion. The conclusion is further supported by the fact that human FH patients in an earlier study exhibited a transient elevation of plasma HDL cholesterol after plasma LDL cholesterol was reduced by plasmapheresis (40), and that no change in HDL- cholesterol levels were observed after in vivo gene delivery of the LDL receptor in LDL receptor knockout mice.

Watanabe rabbits exhibit lower apo AI levels than normal rabbits because of an increase in the rate of apo AI degradation and a decrease in rate of synthesis (41). The increase in apo AI levels after gene delivery in our experiment could be the result of increased apo AI synthesis. Alternatively, a reduction in the transfer of $\mathrm{CE}$ to apo B-containing particles would reduce the clearance of HDL particles, leading to an increase in apo AI.

In epidemiologic studies, there is a strong positive correlation between the level of LDL cholesterol and coronary heart disease (CHD) $(42,43)$. High HDL cholesterol, on the other hand, is thought to reduce the risk of CHD (44). Clinically, the ratio of total cholesterol:HDL cholesterol has proven to be the most reliable indicator of CHD risk. As a result, most CHD therapies have focused on decreasing total cholesterol or increasing HDL cholesterol. Our results demonstrate that there may be an inverse relationship between plasma LDL cholesterol and HDL cholesterol and suggest that reducing LDL-cholesterol levels may further benefit homologous LDL receptor deficient patients by upregulating plasma HDL-cholesterol levels.

\section{Acknowledgments}

We thank Dr. Joseph L. Goldstein for the rabbit LDL-receptor CDNA clone and Dr. Michel Perricaudet for providing the Adv/RSV- $\beta$ gal recombinant vector.

This work was partially supported by National Institutes of Health grants HL-50422 and HL-46860. S. L. C. Woo is an Investigator of the Howard Hughes Medical Institute. R. C. Eisensmith and S. L. C. Woo are equity holders of Gene Medicine Inc., Houston, TX.

\section{References}

1. Goldstein, J. L., and M. S. Brown. 1974. Binding and degradation of low density lipoproteins by cultured human fibroblasts: comparison of cells from a normal subject and from a patient with homozygous familial hypercholesterolemia. J. Biol. Chem. 249:5153-5162.

2. Epstein, F. H., W. D. Block, E. A. Hand, and T. Francis, Jr. 1959. Familial hypercholesterolemia, xanthomatosis and coronary heart disease. Am. J. Med. 26:39-53.

3. Khachadurian, A. K. 1964. The inheritance of essential familial hypercholesterolemia. Am. J. Med. 37:402-407.

4. Khachadurian, A. K., and S. M. Uthman. 1973. Experiences with homozygous cases of familial hypercholesterolemia. A report of 52 patients. Nutr. Metab. 15:132-140.

5. Goldstein, J. L., M. K. Sobhani, J. R. Faust, and M. S. Brown. 1976. Heterozygous familial hypercholesterolemia: failure of normal allele to compensate for mutant allele at a regulated genetic locus. Cell. 9:195-203.

6. Hashim, S. A., and T. B. Van Itallie. 1965. Cholestyramine resin therapy for hypercholesterolemia. JAMA 192:289-293.

7. Endo, A., M. Kuroda, and K. Tanzawa. 1976. Competitive inhibition of 3hydroxy-3-methylglutaryl coenzyme A reductase by ML-236A and ML-236B, fungal metabolites having hypocholesterolemic activity. FEBS (Fed. Eur. Biochem. Soc.) Lett. 72:323-326.

8. Kovanen, P. T., D. W. Bilheimer, J. L. Goldstein, J. Jaramillo, and M. S. Brown. 1981. A regulatory role for hepatic low density lipoprotein receptors in vivo in the dog. Proc. Natl. Acad. Sci. USA. 78:1194-1198.

9. Thompson, G. R., R. Lowenthal, and N. B. Myant. 1975. Plasma exchange in the management of homozygous familial hypercholesterolaemia. Lancet. i: $1208-1211$.

10. Starzl T. E., C. W. Putnam, H. P. Chase, and K. A. Porter. 1973. Portacaval shunt in hyperlipoproteinemia. Lancet. ii:940-944.

11. Bilheimer, D. M., J. L. Goldstein, S. C. Grundy, T. E. Starzl, and M. S Brown. 1984. Liver transplantation provides low density lipoprotein receptors and lowers plasma cholesterol in a child with homozygous familial hypercholesterolemia. N. Engl. J. Med. 311:1658-1664.

12. Watanabe, Y. 1980. Serial inbreeding of rabbits with hereditary hyperlipid- 
emia (WHHL-rabbit). Incidence and development of atherosclerosis and xanthoma. Atherosclerosis. 36:261-268.

13. Yamamoto, T., R. W. Bishop, M. S. Brown, J. L. Goldstein, and D. W. Russell. 1986. Deletion in cysteine-rich region of LDL receptor impedes transport to cell surface in WHHL rabbit. Science (Wash. DC). 232:1230-1237.

14. Ishibashi, S., M. S. Brown, J. L. Goldstein, R. D. Gerard, R. E. Hammer, and J. Herz. 1993. Hypercholesterolemia in low density lipoprotein receptor knockout mice and its reversal by adenovirus-mediated gene delivery. J. Clin. Invest. 92:883-893.

15. Wilson, J. M., M. Grossman, S. E. Raper, J. R. Baker, Jr., R. S. Newton, and J. G. Thoene. 1992. Ex vivo gene therapy of familial hypercholesterolemia. Hum. Gene Ther. 3:179-222.

16. Wilson, J, M., M. Grossman, H. C. Wu, N. R. Chowdhury, G. Y. Wu, and J. R. Chowdhury. 1992. Hepatocyte-directed gene transfer in vivo leads to transient improvement of hypercholesterolemia in low density lipoprotein receptor-deficient rabbits. J. Biol. Chem. 267:963-967.

17. Grossman, M., S. E. Raper, and J. M. Wilson. 1992. Transplantation of genetically modified autologous hepatocytes into nonhuman primates: feasibility and short-term toxicity. Hum. Gene Ther. 3:501-510.

18. Grossman, M., S. E. Raper, K. Kozarsky, E. A. Stein, J. F. Engelhardt, D. Muller, P. J. Lupien, and J. M. Wilson. 1994. Successful ex vivo gene therapy directed to liver in a patient with familial hypercholesterolemia. Nature Genet. 6:335-341.

19. Kozarsky, K. F., D. R. McKinley, L. L. Austin, S. E. Raper, L. D. StratfordPerricaudet, and J. M. Wilson. 1994. In vivo correction of low density lipoprotein receptor deficiency in the Watanabe Heritable Hyperlipidemic Rabbit with recombinant adenoviruses. J. Biol. Chem. 269:13695-13702.

20. Donnelly, T. M., S. F. Kelsey, D. M. Levine, and T. S. Parker. 1991. Control of variance in experimental studies of hyperlipidemia using the WHHL rabbit. J. Lipid Res. 32:1089-1098.

21. Sudhof, T. C., J. L. Goldstein, M. S. Brown, and D. W. Russell. 1985. The LDL receptor gene: a mosaic of exons shared with different proteins. Science (Wash. DC). 228:815-822.

22. Graham, F. L., and L. Prevec. 1991. Manipulation of adenovirus vector. In Methods in Molecular Biology: Gene Transfer and Expression Protocols, Vol. 7. E. J. Murray, editor. The Human Press. Clifton, NJ. 109-128.

23. Fang, B., R. C. Eisensmith, X. H. C. Li, A. Shedlovsky, W. Dove, and S. L. C. Woo. 1994. Gene therapy for phenylketonuria: phenotypic correction in a genetically deficient mouse model by adenovirus-mediated hepatic gene transfer. Gene Ther. 1:247-254.

24. Kay, M. A., C. N. Landen, S. R. Rothenberg, L. A. Taylor, F. Leland, S. Wiehle, B. Fang, D. Bellinger, M. Finegold, A. R. Thompson, et al. 1994. In vivo hepatic gene therapy: complete albeit transient correction of factor IX deficiency in hemophilia B dogs. Proc. Natl. Acad. Sci. USA. 91:2353-2357.

25. Cristiano, R. J., L. C. Smith, and S. L. C. Woo. 1993. Hepatic gene therapy: adenovirus enhancement of receptor mediated gene delivery and expression in primary hepatocytes. Proc. Natl. Acad. Sci. USA. 90:2122-2126.

26. Goldstein, J. L., S. K. Basu, and M. S. Brown. 1983. Receptor-mediated endocytosis of low-density lipoprotein in cultured cells. Methods Enzymol. 98:241-260.

27. Mims, M. P., M. R. Soma, and J. D. Morrisett. 1990. Effect of particle size and temperature on the conformation and physiological behavior of apolipoprotein E bound to model lipoprotein particles. Biochemistry. 29:6639-6647.

28. Kay, M. A., Q. Li, T. J. Liu, F. Leland, C. Toman, M. Finegold, and S. L. Woo. 1992. Hepatic gene therapy: persistent expression of human alpha 1- antitrypsin in mice after direct gene delivery in vivo. Hum. Gene Ther. 3:641647.

29. Li, Q. T., M. A. Kay, M. Finegold, L. D. Stratford-Perricaudet, and S. L. C. Woo. 1993. Assessment of recombinant adenoviral vectors for hepatic gene therapy. Hum. Gene Ther. 4:403-409.

30. Burstein, M., H. R. Scholnick, and R. Morein. 1970. Rapid method for the isolation of lipoproteins from human serum by precipitation with polyanions. J. Lipid Res. 11:583-595.

31. Lin, R. C. 1986. Quantification of apolipoproteins in rat serum and in cultured rat hepatocytes by enzyme-linked immunosorbent assay. Anal. Biochem. 154:316-326

32. Jiao, S., T. C. Cole, R. T. Kitchens, B. Pfleger, and G. Schonfeld. 1990. Genetic heterogeneity of lipoproteins in inbred strains of mice: analysis by gelpermeation chromatography. Metab. Clin. Exp. 39:155-160.

33. Allain, C. C., L. S. Poon, C. S. G. Chan, W. Richmond, and P. C. Fu. 1974. Enzymatic determination of total serum cholesterol. Clin. Chem. 20:470475.

34. Zabner, J., L. A. Couture, R. J. Gregory, S. M. Graham, A. E. Smith, and M. J. Welsh. 1993. Adenovirus-mediated gene transfer transiently corrects the chloride transport defect in nasal epithelia of patients with cystic fibrosis. Cell. 75:207-216.

35. Vincent, N., T. Ragot, H. Gilgenkrantz, D. Couton, P. Chafey, A. Gregoire, P. Briand, J. C. Kaplan, A. Kahn, and M. Perricaudet. 1993. Long-term correction of mouse dystrophic degeneration by adenovirus-mediated transfer of a minidystrophin gene. Natural Genet. 5:130-134.

36. Ha, Y. C., and P. J. Barter. 1982. Differences in plasma cholesteryl ester transfer activity in sixteen vertebrate species. Comp. Biochem. Physiol. 71B:265269.

37. Hayek, T., T. Chajek-shaul, A. Walsh, L. B. Agellon, P. Moulin, A. R. Tall, and J. L. Breslow. 1992. An interaction between the human cholesteryl ester transfer protein (CETP) and apolipoprotein A-I genes in transgenic mice results in a profound CETP-mediated depression of high density lipoprotein cholesterol levels. J. Clin. Invest. 90:505-510.

38. Son, Y. S. C., and D. B. Zilversmit. 1986. Increased lipid transfer activities in hyperlipidemic rabbit plasma. Arteriosclerosis. 6:345-351.

39. Inazu, A., J. Koizumi, H. Mabuchi, K. Kajinami, and R. Takeda. 1992. Enhanced cholesteryl ester transfer protein activities and abnormalities of high density lipoproteins in familial hypercholesterolemia. Horm. Metab. Res. 24:284288.

40. Parker, T. S., B. R. Gordon, S. D. Saal, A. L. Rubin, and E. H. Ahrens, Jr. 1986. Plasma high density lipoprotein is increased in man when low density lipoprotein (LDL) is lowered by LDL-pheresis. Proc. Natl. Acad. Sci. USA. 83:777-781.

41. Saku, K., K. Yamamoto, T. Sakai, T. Yanagida, K. Hidaka, J. Sasaki, and K. Arakawa. 1989. Kinetics of HDL-apo A-I in the WHHL rabbit, an animal model of familial hypercholesterolemia. Atherosclerosis. 79:225-230.

42. Lipid Research Clinics Program. 1984. The lipid research clinics coronary primary prevention trail results. I. Reduction in incidence of coronary heart disease. JAMA 251:351-364.

43. Lipid Research Clinics Program. 1984. The lipid research clinics coronary primary prevention trail results. II. The relationship of reduction in incidence of coronary heart disease to cholesterol lowering. JAMA 251:365-374.

44. Expert Panel on Detection, Evaluation, and Treatment of High Blood Cholesterol in Adults. 1993. Summary of the second report of the national cholesterol education program (NCEP) expert panel on detection, evaluation, and treatment of high blood cholesterol in adults (adult treatment panel II). JAMA 269:3015-3023. 